\title{
Women's resistance to domestic violence during COVID-19 pandemic: A study from Indonesia
}

\section{Perlawanan perempuan terhadap kekerasan dalam rumah tangga selama pandemi COVID-19: Sebuah studi dari Indonesia}

\author{
Siti Mas'udah ${ }^{\bowtie}$, Lutfi Apreliana Megasari, \& Muhammad Saud \\ Department of Sociology, Faculty of Social and Political Sciences, Universitas Airlangga \\ Surabaya, 60286, East Java Province, Indonesia \\ E-mail of corresponding author: siti.masudah@fisip.unair.ac.id
}

\begin{abstract}
COVID-19 pandemic affected the increasing frequency and intensity of a husband and wife's interaction. The pandemic further worsened domestic violence experienced by women, and this has made them resist the violence. This study aims to unravel domestic violence and women's resistance. The research used a qualitative method on women who experienced domestic violence amid the COVID-19 pandemic. The findings suggest that the resistance was triggered by numerous internal conflicts, such as declining income and increasingly diverse household conflicts during the pandemic. Women spontaneously resist against verbal, physical, and psychological abuse to save themselves from harm and to protect their dignity. The resistances are demonstrated in various ways, including fighting the husband back, verbal abuse, shouting, threatening to divorce, scratching, and punching the husband. Additionally, women also resorted to passive resistance by giving the silent treatment, staying away, stopping communication, not sleeping in the same bed, and refusing to serve the husband. This resistance exhibited women's awareness to defend their rights. Women did realize that they have the right to fight back as a manner of combating gender inequality.
\end{abstract}

Keywords: domestic violence; gender awareness; gender inequality; violence against women; women’s resistance

Abstrak

Pandemi COVID-19 berdampak pada meningkatnya frekuensi dan intensitas interaksi suami istri. Pandemi ini semakin memperburuk kekerasan dalam rumah tangga yang dialami perempuan, dan hal ini membuat mereka melawan kekerasan tersebut. Studi ini bertujuan untuk mengungkap kekerasan dalam rumah tangga dan resistensi perempuan. Studi ini menggunakan metode kualitatif pada perempuan yang mengalami kekerasan dalam rumah tangga di tengah pandemi COVID-19. Temuan menunjukkan bahwa resistensi dipicu oleh berbagai konflik internal, seperti penurunan pendapatan dan konflik rumah tangga yang semakin beragam selama pandemi. Perempuan secara spontan melawan pelecehan verbal, fisik, dan psikologis untuk menyelamatkan diri dari bahaya dan untuk melindungi martabat mereka. Perlawanan tersebut ditunjukkan dengan berbagai cara, antara lain melawan balik suami, mencaci maki, berteriak, mengancam cerai, mencakar, dan meninju suami. Selain itu, perempuan juga melakukan perlawanan pasif dengan memberikan perlakuan diam, menjauhi, menghentikan komunikasi, tidak tidur di ranjang yang sama, dan menolak melayani suami. Perlawanan ini menunjukkan kesadaran perempuan untuk membela hak-haknya. Perempuan memang menyadari bahwa mereka memiliki hak untuk melawan sebagai cara memerangi ketidaksetaraan gender.

Kata Kunci: kekerasan dalam rumah tangga; kesadaran gender; ketidaksetaraan gender; kekerasan terhadap perempuan; perlawanan perempuan

\section{Introduction}

Domestic violence is a social problem that depicts an unhealthy spousal relationship. It occurs regardless of gender; however, many cases refer to women as the primary victim of violence due to religious dogma and the patriarchal culture of women subordination. Generally, women decide to cope with violence by fighting back or counter-controlling the husband (Johnson 2006). In this case, women constrain the violence to avoid the worst consequence of it. 
Some women resist violence due to some inducement that makes them confident enough to fight (Esqueda \& Harrison 2005, Scarduzio et al. 2016, Anderson \& Umberson 2001). Sometimes, women decide to seek help from others, which help them to have more courage to fight the husband. On the other side, media and news could also contribute to women's courage to contend on violence.

Bouffard et al. (2008) emphasized that women's resistance to violence often ended in the hands of the police. The resistance itself backfired for women, especially when it goes to a certain extreme degree, such as homicide. Unfortunately, such a defense mechanism is often considered a crime. Previous studies on this topic also highlighted that if a woman does end up resisting, she is stigmatized as a mean person (Sokoloff \& Dupont 2005, Flowers 2015).

Sometimes, women think twice before resisting the violence. However, some women stay still and doubt their actions. In this case, resistance could result infiling a police report or leaving their relationship (Campbell \& Mannell 2015). Women often come to file a report to the police or relevant non-government organizations covered in bruises and injuries to strive for justice. A study done by Sugg (2015) found that women's resistance to violence is regarded as a defense mechanism or constraining their partner. Therefore, aside from filing reports, women are also fighting back with counter-violence to their husbands.

The resistance is often associated with a spontaneous reaction towards an abusive action (Javaid 2015, Johnson 2006, Mason 2005). Instead of crying, women resist instinctively to protect their dignity and dignity and are unwilling to be defeated. As a result, they counter the abuse with more verbal or physical abuse towards the husband. Bohall et al. (2016) suggest that violence resistance refers to a case if victims can resist coercion to control it through retaliation. These resistances symbolize that the women have full authority of themselves above their partner's control.

However, recent studies found that resistances are considered immoral. Despite this consideration, women persist in protecting themselves to live happily (Vecina et al. 2015, LeCouteur \& Oxlad 2010, Yount 2010). Patriarchal culture believes that it is unsuitable for a woman to fight back. Hence, women should obey their husbands. Moreover, the men tend to blame the women when their relationship starts to break by telling them that they are unable to look after their husbands. Gulliver \& Fanslow's (2015) study in New Zealand found that only $20 \%$ of the women filed reports of their violent experience and fought back, while only $4 \%$ fight back with counter-abuse. This number indicated that most women did not resist violence due to the social constraints and cultural system that subjugates women's power over men.

Women's resistance to intimate partner violence is a form of brave act because of unfair treatment. Resistance is also pointed as defensive violence, in which it occurs regardless of age barrier and if the conflicting partner is equally persistent in committing violence (Muftić et al. 2012, Hollander 2009, Muftić et al. 2007). In this case, women tend to attack and injure their opponents. Previous authors note that domestic violence victims generally resist the violence despite the risk and fear, as well as acknowledging that every act of resistance will be followed by worse abuses (Wilson et al. 2015, Goodman et al. 2005, Rajah 2007). It is because women become more vulnerable to get involved in a worse abuse when they have the urge to fight back, mainly when they are within an influential patriarchal either culture or society. Women's resistance is considered something that is barbarous and ignores the usual norms, which results in negative labeling. However, Burnette (2015) explains that this resistance will be a life-changing point for women to fight and free themselves from abusive partners. Therefore, a woman must oppose such conditions.

Unfortunately, not all defensive actions against domestic violence are considered as acts of protection in the eyes of the law (Johnson 2005, Ballan \& Freyer 2012, Serran \& Firestone 2004). Such beliefs emerge from the conservative culture of a patriarchal society that considers men's higher position over women. In any case, women's violence resistance is considered as a negative stand instead of a 
defensive mechanism. Cavanagh (2013) explained that women's resistance comes in various forms, such as realizing defensive strategies, stopping or reducing the abuse, and realizing the subordination. These forms of resistance showed women's awareness of abusive actions conducted by their partners.

However, despite the awareness of resistance rights, some women remain hesitant to resist the abuse due to the possible higher risk of worse violence, which often occurs in traditional society. Previous studies mentioned that women tend to file a report of violence instead of resisting to prevent worse risks (Myhill 2017, Lichtenstein \& Johnson 2009, Levesque et al. 2008). These cases demonstrated the exemplification of women's anxiety about the worst-case scenario.

Other actors, such as non-governmental organizations, also took part in reducing domestic violence. The violence victim joins gender equality communities to diminish the fury by campaigning in social and political spaces (Hall 2009). Women with high awareness will be in favour of campaign anti-domestic violence. Unfortunately, not all women have the opportunity to save their life from such an abusive environment.

Some women still put up with in an abusive household. Many recent studies (Ahmed \& Elmardi 2005, Miller \& Meloy 2006, Burman et al. 2004) had shown that women choose to stay silent, stay calm, cry, tell the relatives, or fight back when they experienced violence. Staying silent, crying, and refusing to resist violence indicates that the woman has no power and is in fear of the breaking off the relationship. The latter case substantiated the low bargaining power and that the women had no economic independence, making them unable to carry out the resistance.

Evidence suggests that women's resistance is carried out by taking control of the conflict or the partner, defending themselves, stopping violence, attacking their partners, or visiting women's commission (Kelly \& Johnson 2008, Johnson 2011, DeKeseredy \& Dragiewicz 2007). Victims of violence prefer to speak up when they are aware of things they have been going through. Besides retaliation, women will also fight back by withholding economic accessand overseeing partner's communication with outsiders. To some extent, they dare to threaten their husband for a divorce.

Allen's (2011) study states that violent experience enables women to maintain their love of their partner and expect a better family relationship. Therefore, women will resist with a strategic mechanism to reconstruct the current relationship. At times, resistances does not mean to append the household damage, but to subdue the husband or an act of fortifying. Resistances are not always physical; it often occurs in other ways to control the husband. Therefore, these cases showed a woman's attempt to save the family.

Recent studies have been assessing domestic violence against women. However, studies on women's resistance have much explored, despite the relevant cases with domestic violence. This research aims to unravel women's resistance towards domestic violence, especially during the COVID-19 pandemic, where instances of violence have increased. Ironically, the COVID-19 pandemic contributes to the rising number of abuse against women. Thus, women's resistance towards violence is an interesting topic to be addressed due to their courage to go against patriarchal society.

\section{Research Methods}

This research employs a qualitative method. The data was collected from March 2020 to June 2021 from female victims of violence who work in the public sector or are housewives in Surabaya, Indonesia. In this study, an in-depth interview of the victims was conducted in order to identify how women resist the violence during COVID-19.

The interview conveyed to create a direct way for the researcher to conduct data analysis. Furthermore, it was expected that the interview would inform the researcher regarding the violence in a detailed manner. Questions were asked through face-to-face and phone interviews with a guide of interview. 
Following the interview, the data is categorized according to the research topic and analyzed with some theories and existing relevant previous studies.

\section{Results and Discussion}

Women's resistance towards violence carves out an escape route from a gender inequality situation. Several reports have shown that women's resistance is a measure to protect themselves and their children (Mkandawire-Valhmu et al. 2016, Callaghan 2015, Scott \& King 2007). The resistance act was meant to exemplify their children to fight against the violence because abusive husbands tend to spill over their anger to children. Thus, women are trying to contend the latter case to protect themselves and their children. McCarthy's et al. (2016) study on women's resistance found that women could withstand the violence by repudiation, stand up against the perpetrators, counter-hitting, and refuse to forgive, use contraception secretly and report the violence to authorities. Such courage is often shown directly by hurting their partner and indirectly indicated through resistance intentions.

\section{Driving factors of women's resistance against domestic violence}

Economic difficulties and social restriction have an impact on the frequent occurrence of a household conflict due to the spousal engagement at home. One interviewee, DIA, argued that she experienced long-standing violence despite the dual-career family and settled condition. DIA stressed that she would argue with her husband over small things.

"Both me and my husband refused to give in, and the conflict occurs in verbal and physical abuse. My husband is very irritable and often ended up hurting people if enraged. Moreover, stepchildren also contributed to this part."

Previous studies mentioned that men committed violence against women to frighten them. However, victims can carry out resistance against the abuse; some decide to seize a law measure (Brickell 2015, Payne \& Wermeling 2009, Randall 2010). Nonetheless, a traditional family approach characterized men as "leaders of the family" to maintain a household. The task itself serves as legitimacy for a man to show dominance. Therefore, domestic violence becomes prevalent in a patriarchal family.

In the theory of patriarchy (Walby 1990), it is stated that patriarchy is a social system in which men's practices dominate, oppress, and exploit women. Walby reconstructed patriarchy at several levels. In an abstract concept, patriarchy is in the form of a social system, while at the non-abstract level, patriarchy consists of six structures which include patriarchal modes of production, patriarchal relations within the state, male violence against women, patriarchal relations in sexuality, and patriarchal relations in cultural institutions.

Based on Walby's theory, this study shows that domestic violence is considered commonplace in patriarchal societies. Men from childhood have been socialized to become leaders in the family. Women are educated to obey their husbands. Women must be responsible for domestic work, even though they also have roles in the public sphere. When women are victims of violence, society perceives them as the guilty party for disobeying men. The patriarchal Javanese society has continued to develop this discourse from generation to generation so that violence against women in the family continues because women are considered as the second sex.

Informant KIA also experienced domestic violence during the pandemic due to disagreements and the couple's refusal to concede. KIA and her husband frequently quarrel to the extent of physical abuse, even long before the pandemic.

"I have had many family conflicts, especially with my husband. I also received physical abuse. But, I realized that this fight was triggered by the two of us. When fighting, I often bring up my husband's past problems, and as a result, I was physically injured. I did it because I was annoyed.” 
KIA's experience of violence is practically caused by the couple's attitude, which is in line with DIA's experience. When KIA was annoyed, she brought up her husband's problematic past. Such action triggers her husband to become enraged and he committed physical violence.

Any woman would have the desire to counter abusive treatment regardless of their background. Stuart's (2010) study states that women prioritize emotions, which triggers uncontrollable stress and drives them to attack their partners. It is proof by KIA's impulsive action of violence against her husband's mistreatment. KIA did that to save her dignity by resisting with verbal manners. Such actions are following several studies that mentioned women's resistance is a form of response to the abuse and does not meant to control the partner (Kernsmith 2010, Whitaker 2013).

Another interviewee, RAC, a dentist, portrays a different case when women can resist violence. This attests that women do have show resistance if they have something that can be relied on, called income. The latter case did not happen in the case of women who rely so much on husbands, which makes them hesitate to fight back due to the lack of independent economic resources, especially if the women live in a patriarchal society.

This study found that violence occurs both for women who work in the public sector and housewives. In this case, resistance was carried out as a response to continuous abusive treatment committed by their partner. Women spontaneously do the same thing to the husbands as an act of retaliation for the longstanding violence. Thus, it can be argued that women no longer stay silent over the mistreatment they faced.

\section{Form of women's resistance against domestic violence during COVID-19 pandemic}

Women resisted violence to reduce the amount of abuse and self-defense, although resisting could escalate the abusive treatment itself. Men carried out violence to frighten the victims, but some victims retaliate and even choose to enforce the law (Brickell 2015, Payne \& Wermeling 2009, Randall 2010). Furthermore, Purvin (2003) also mentioned that women consistently try not to come back to their husbands after experiencing violence. At this point, the women have had enough violence, and they refuse to return to avoid the possibility of fury re-occurrence. More women are brave enough to retaliate due to the globalization trends that support gender equality awareness, implicated by protests and social movements (Fulu \& Miedema 2015, Radford \& Tsutsumi 2004, Armstrong 2004). Other actors, such as non-governmental organizations, also play a role to liberate women from domestic violence.

Informant PIN is brave enough to counter verbal abuses by divorce enforcement. PIN, who is a dentist, is unafraid of the husband's mistreatment, and she believes such things should be given a warning.

"Once, I warned my husband verbally. I said "If you continue to be stubborn, or do the same, even worse mistakes towards me, I am not afraid to file a divorce". I said this because I am tired of it."

PIN countered her husband's abuse verbally as a warning. She said that she had more significant conflict long before the pandemic and unafraid of mistreatment. She had to preserve the marriage, but if her husband continues to mistreat her, she does not hesitate to resist.

PIN's resistance is possible due to her high bargaining position as a dentist, which makes it advantageous for her to resist violence. Hollander's (2005) study emphasized that once a woman refuses to fight back, the violence will become more intense because the perpetrators discern there is no space for them to retaliate. Thus, resistance is vital to tear down the "weak-woman" stereotypes.

Educated women will be aware of gender inequality and do not hesitate to go against violence to protect their sexual rights (Leclerc et al. 2016). It is the case for PIN, in which she retaliates due to 
her awareness. Violence against women is a violation of rights. Therefore, a woman needs to have an awareness of domestic violence. Resistance is a form of resilience and empowerment to free themselves from harassment (Warner et al. 2005, Mason \& Pulvirenti 2013, Labronici 2012). Other than that, resistance waives off unhealthy family and women imprisonment under the pretext of marital ties.

The wife's higher bargaining position than the husband does not always hinder domestic violence. One of the interviewees, NAB, has a bachelor degree while her husband held a master's degree. NAB spontaneously countered verbal violence with the same verbal violence as well. It hurts her feeling when the husband spits out harsh words.

"I do not like to be treated harshly, whatever the reason is. Even if he does not mean any harm, if he does it harshly, I really do not like it. For example by shouting and scolding. I was back angry to him, so he learned his lesson. Sometimes I leave it for a long time and keep quiet as I don't want to talk at all."

$\mathrm{NAB}$ resisted in the hope of the husband not doing the same thing ever again. NAB realizes that she has a lower educational background than her husband, but she does not accept such reason could be a justification for the abusive behavior. Although she does not have high bargaining power, she still objects to rough treatment by any means.

Violence committed by husbands will continue to occur if the victim stays silent and surrenders. Masculinity does not always affiliate with violence; however, to some extent, masculinity expects women to fall into men's control of physical and sexual power and justifies threatening the wife (Jewkes et al. 2015). A violent man has the desire to control his partner and will continue to dominate more if there is no resistance.

Yount's (2005) study found that independent women who have more economic resources will show intolerance to any harassment and violence directed at them and are willing to leave abusive relationships as opposition toward male domination. In this case, independent women will use their resources as a shield to leave a violent husband. However, such cases did not meet NAB's condition. NAB is a housewife with no economic resources, but she has no hesitation in resisting violence.

NAB has no fear of resisting violence, while this is usually not the case for women who have no income. Some women do not fight back due to the fear of losing the future, fear of law enforcement, job loss, child custody, and fear of getting unloved (Dasgupta 2002, Todd et al. 2002, Hardesty \& Ganong 2006). Women with no job tend to think repeatedly before resisting due to the risk of being left behind by the husband. NAB's maintaining of her status quo as a mother and wife who should not be underestimated. It is in line with Childress et al. (2017) findings of Kyrgyz women's strategy to prevent and minimize violence by maintaining women's status quo, considering the embedded value of violence in society.

The same thing happened to AUL, where she also tried to resist violence. She also does not have economic bargaining power over her husband. AUL's husband is a member of the military who is highly educated and has high influence at home. Despite all of that, AUL's husband often verbally and physically abuses her, which happened before the pandemic.

\footnotetext{
"When my husband got angry, I tend just to keep silent. If he gets angry, it is very horrible; he yelled and threw things. Once, he threw a bottle at me. I was once grumbled over his anger, though I know this does not show any firmness at all, but I feel scared. Sometimes I leave him alone, and refuse to talk. Nor have I ever threatened him to divorce."
}

AUL's violent experience is tragic due to the verbal and physical abuse she received, but her resistance is limited to silence and showing resentment by grumbling. Knowing that her husband serves as militia, such a condition makes her unable to do much against her husband. She had to accept every norm and rule given by the state to be obeyed. Thus, AUL's domestic life is observed by the state, and it makes her have no courage to resist. 
The preliminary studies mentioned that some women choose to stay silent because they do not want to worse violence to occur, but others choose to protect themselves by resisting or counter-violence (Jayanthi 2009, Brecklin 2002, Walton-Moss et al. 2005). Women who prefer to stay silent consider that counterviolence is risky because men tend to reject women resistance. It was experienced by AUL, who fought subtly by staying quiet and grumbling since she is the wife of a militia.

Sukmawati's (2014) study states that women's resistance will never be the same as violence committed by a husband and does not have the same impact. Although women counter violence with violence, this will never be equal to the husband. Such abuses are considered as masculinity and male domination, while the wife's resistance is a form of self-defense. Besides, Zink et al. (2006) study also mention that older women victims of violence tend not to resist and end up remaining in abusive relationships, as well as trying hard to find any meaning in a situation that is impossible for them to change. It shows that women's resistance is often disproportionate to the risk and trauma.

A distinct circumstance befalls upon one of the interviewees, DIA, in which she bravely resists violence. DIA experienced domestic violence before and during the pandemic. DIA's situation is a rare case of a highly educated and settled woman experiencing violence, which contravenes previous studies' foundings. DIA is a master's degree graduate and working as a civil servant while her husband only holds a vocational diploma. Higher education does not guarantee her freedom from violence. Besides, the fact that she remarried also impacted the frequency of conflicts between her and her husband.

"If my husband shouted, hit, or scratched me, I will do likewise. He often complained over my loud voice, and I answered, 'This is me, no one can change it. If you want to hit me, then hit me!' and then I ended up hitting myself."

DIA felt her husband's unfair treatment towards her children from a previous marriage. Meanwhile, DIA's husband also often forbids her to travel far for business matters. Therefore, she does not hesitate to fight her husband.

Previous studies have shown that women's mental state is usually strong enough to overcome a violent husband by preventing, detaining, stopping or opposing it, even employs improved strategies to protect themselves and their children (Bhandari et al. 2011, Kocot \& Goodman 2003, Meyer et al. 2009). In DIA's case, she experienced worse violence after the resistance. She ended up in injuries and bruises, and so did her husband. However, both of them decided to preserve the marriage, even though the children ask them to divorce.

Rizo's (2015) study on domestic violence found that survivors of domestic violence use coping strategies to counterattacks, such as arguing, shouting, talking back, and physically attacking. Unfortunately, physical attacks only worsened the abuse. Such strategies were also found in DIA's resistance. DIA admitted that when she received violence from her husband, she spontaneously did the same thing. Even when her husband was enraged, she was not afraid to argue or shout at him. On the contrary, this only stimulates the violence to a more severe degree.

Hollander \& Eihwohner (2004) stated in their theory that resistance has two aspects, including action and opposition. Hollander \& Eihwohner see resistance as including actions, which are carried out in physical, verbal, and cognitive forms. In addition, according to Hollander \& Eihwohner, opposition is not defined as power but on discursive ideas and values.

Other previous studies have suggested that there are women who fight back by attacking and committing suicide instead of avoiding any contact with the husband (Sayem et al. 2013, Rizo et al. 2017, Rizo 2013). Women who strike back are brave enough to risk their dignity as women who do not deserve to be violated. However, women's resistance is hampered by patriarchal values in which women are required to be gentle and have to sacrifice their interest to maintain a harmonious family (Nurhayati 2015). 
Another resistance attains in the form of avoidance. As one of the interviewees, KIA, has commented that she chose to distance herself from her husband, threatened divorce, and sleep separately with her husband.

"If I fought and received violence, I choose to stay away from my husband, sleeping separately, refuse to serve and communicate with him. I once threatened him to divorce. But I do not want to fight back, and it is risky for me to do it."

KIA's resistance against her violent husband showed that she did not want to be involved in further violence. KIA realized that if she fights vigorously, she will be highly vulnerable to experience more severe violence. Therefore, she only resists by giving threats and refusing to communicate. KIA even has never responded to her husband's violence verbally.

KIA's passive resistance does not imply that she surrendered, but it defined her effort to resist, although she did not respond to it with the same amount of violence. Only a few women openly oppose their husbands to ensure their children's safety, while there are still many women who try to make peace and surrender to their husbands' demands (Chimah et al. 2015, Schaefer et al. 2019). Thus, women who resist passively have their determination to defend the children or be worried about setting a bad example for them. Liang et al. (2005) also found that formal and informal support also contributes to a women's bravery to resist the violence.

Galtung (1990) explains violence in his theory that there are three forms of violence, namely direct violence, structural violence, and cultural violence. The typology of violence according to Galtung explains that violence is not only in the form of direct attacks or aggresive actions. Sometimes violence is not always about physical action, but it can also take the form of impoverishment, economic imbalance, and socio-political injustice. On the other hand, violence becomes a cultural aspect where violence is perpetuated on cultural, religious norms, and extended to other forms such as art and language. In this study, patriarchy as a norm which is developed and socialized towards individuals since childhood is the cause of the perpetuation of domestic violence. Moreover, patriarchy is supported by religious norms which further strengthen male domination in the family.

Meanwhile, an additional manner of resistances against violence could extend to police intervention, divorce, homicide, showing an actual act, and concerning uncontrolled individuals (Mary 2020). In KIA's case, she used the strategy of showing a non-violent act. Unfortunately, KIA has yet to report to the authorities for the violence. Women's resistance often clashes with religious and cultural dogmas that blaming the victims and emphasize the importance of maintaining marriage (Hassouneh-Phillips 2003, Ahinkorah et al. 2018, Ali et al. 2012).

Additional forms of resistance are trying to change the partner's behavior and balancing power by opposing the control exercised by partners (Goodman et al. 2003, Anderson \& Lo 2010). Women's resistance is a form of action in which women reject male authority due to the patriarchal culture that identified women as men's submission. Marshall \& Furr's study (2010) states that women's resistance indicates opposition towards patriarchal hegemony. Therefore, women's resistance is an effort to combat gender injustice in a household.

Therefore, women's resistance against domestic violence could occur in the form of shouting at the husband, threatening divorce, silent treatment, physical violence (hitting and scratching), staying away, and not sleeping in the same bed.

\section{Conclusion}

Along with the increasing domestic violence that occurred during the pandemic due to several impacts or family problems, victims of domestic violence do not hesitate to resist. Resistance does not necessarily 
mean to control a partner, but solely as an attempt to avoid further severe violence. When women resisted, they risked their bodies for physical and mental wounds. Additionally, harmful stereotypes over women's resistance still exist, arising from the patriarchal society.

In this case, women put up a latent and manifest resistance that comes in various forms, ranging from silent treatment, refusing to serve the husband, and attacking their husbands. These are the implications of women's awareness to defend and maintain their rights. Women realize that they have the right to fight back against the violence. Finally, resistance is an effort to fight gender injustice that has been experienced by women in the family realm.

\section{References}

Ahmed AM \& Elmardi AE (2005) A study of domestic violence among women attending a medical centre in Sudan. La Revue de Santé de la Méditerranée orientale 11 (1-2):164-174.

Allen M (2011) Violence and voice: Using a feminist constructivist grounded theory to explore women's resistance to abuse. Qualitative Research 11 (1):23-45.

Anderson KL \& Umberson D (2001) Gendering violence. Gender \& Society 15 (3):358-380.

Anderson AS \& Lo CC (2010) Intimate partner violence within law enforcement families. Journal of Interpersonal Violence 26 (6):1176-1193.

Armstrong E (2004) Globalization from below: AIDWA, foreign funding, and gendering anti-violence campaigns. Journal of Developing Societies 20 (1-2):39-55.

Ballan MS \& Freyer MB (2012) Self-defense among women with disabilities. Violence Against Women 18 (9):1083-1107.

Bhandari S, Bullock LFC, Anderson KM, Danis FS, \& Sharps PW (2011) Pregnancy and intimate partner violence: How do rural, low-income women cope? Health Care for Women International 32 (9):833-854.

Bohall G, Bautista MJ, \& Musson S (2016) Intimate partner violence and the Duluth Model: An examination of the model and recommendations for future research and practice. Journal of Family Violence 31 (8):1029-1033.

Bouffard LA, Wright KA, Muftić LR, \& Bouffard JA (2008) Gender differences in specialization in intimate partner violence: Comparing the gender symmetry and violent resistance perspectives. Justice Quarterly 25 (3):570-594.

Brecklin LR (2002) The role of perpetrator alcohol use in the injury outcomes of intimate assaults. Journal of Family Violence 17 (3):185-197.

Brickell K (2015) Towards intimate geographies of peace? Local reconciliation of domestic violence in Cambodia. Transactions of the Institute of British Geographers 40 (3):321-333.

Burman E, Smailes SL, \& Chantler K (2004) 'Culture' as a barrier to service provision and delivery: Domestic violence services for minoritized women. Critical Social Policy 24 (3):332-357.

Burnette CE (2015) Disentangling indigenous women's experiences with intimate partner violence in the United States. Critical Social Work 16 (1).

Callaghan J (2015) Mothers and children? Representations of mothers in research on children's outcomes in domestic violence. Psychology of Women Section Review 17: 13-20.

Campbell C \& Mannell J (2015) Conceptualising the agency of highly marginalised women: Intimate partner violence in extreme settings. Global Public Health 11 (1-2):1-16.

Cavanagh K (2003) Understanding women's responses to domestic violence. Qualitative Social Work: Research and Practice 2 (3):229-249.

Childress S, Gioia D, \& Campbell JC (2017) Women's strategies for coping with the impacts of domestic violence in Kyrgyzstan: A grounded theory study. Social Work in Health Care 57 (3):164-189.

Chimah UC, Adogu POU, \& Ilika AL (2015) Impact of intimate partner violence and coping strategies adopted among women in military and civilian communities of Abuja Nigeria. Scholars Journal of Applied Medical Sciences (SJAMS) 3 (1B):131-138.

Dasgupta SD (2002) A Framework for understanding women's use of nonlethal violence in intimate heterosexual relationships. Violence Against Women 8 (11):1364-1389. 
DeKeseredy WS \& Dragiewicz M (2007) Understanding the complexities of feminist perspectives on woman abuse: A commentary on Donald G. Dutton's rethinking domestic violence. Violence Against Women 13 (8):874-884.

Dhungel S, Dhungel P, Dhital SR, \& Stock C (2017) Is economic dependence on the husband a risk factor for intimate partner violence against female factory workers in Nepal? BMC Women's Health 17 (1).

Esqueda CW \& Harrison LA (2005) The influence of gender role stereotypes, the woman's race, and level of provocation and resistance on domestic violence culpability attributions. Sex Roles 53 (11-12):821-834.

Flowers R (2015) Refusal to forgive: Indigenous women's love and rage. Decolonization: Indigeneity, Education \& Society 4 (2):32-49.

Fulu E \& Miedema S (2015) Globalization and changing family relations: Family violence and women's resistance in Asian Muslim societies. Sex Roles 74 (11-12):480-494.

Galtung J (1990) Cultural violence. Journal of Peace Research 27 (3). https://doi.org/10.1177\% 2F0022343390027003005.

Goodman L, Dutton MA, Weinfurt K, \& Cook S (2003) The intimate partner violence strategies index. Violence Against Women 9 (2):163-186.

Goodman L, Dutton MA, Vankos N, \& Weinfurt K (2005) Women's resources and use of strategies as risk and protective factors for reabuse over time. Violence Against Women 11 (3):311-336.

Gulliver P \& Fanslow JL (2015) The Johnson typologies of intimate partner violence: An investigation of their representation in a general population of New Zealand women. Journal of Child Custody $12(1): 25-46$.

Hall N (2009) East Timorese women challenge domestic violence. Australian Journal of Political Science 44 (2):309-325.

Hardesty JL \& Ganong LH (2006) How women make custody decisions and manage co-parenting with abusive former husbands. Journal of Social and Personal Relationships 23 (4):543-563.

Hollander JA (2005) Challenging despair: Teaching about women's resistance to violence. Violence Against Women 11 (6):776-791.

Hollander JA (2009) The roots of resistance to women's self-defense. Violence Against Women 15 (5):574-594.

Hollander JA \& Einwohner RL (2004) Conceptualizing resistance. Sociological Forum 19: 533-554. https://doi.org/10.1007/s11206-004-0694-5.

Hassouneh-Phillips D (2003) Strength and vulnerability: Spirituality in abused American Muslim women's lives. Issues in Mental Health Nursing 24 (6-7):681-694.

Javaid A (2015) The role of alcohol in intimate partner violence: Causal behaviour or excusing behaviour? British Journal of Community Justice 13 (1):75-92.

Jayanthi ET (2009) Faktor-faktor penyebab terjadinya kekerasan dalam rumah tangga pada survivor yang ditangani oleh lembaga sahabat perempuan Magelang. Dimensia 3 (2):33-50.

Jewkes R, Flood M, \& Lang J (2015) From work with men and boys to changes of social norms and reduction of inequities in gender relations: A conceptual shift in prevention of violence against women and girls. The Lancet 385 (9977):1580-1589.

Johnson MP (2005) Domestic violence: It's not about gender-or is it? Journal of Marriage and Family $67(5): 1126-1130$.

Johnson MP (2006) Conflict and control. Violence Against Women 12 (11):1003-1018.

Johnson MP (2011) Gender and types of intimate partner violence: A response to an anti-feminist literature review. Aggression and Violent Behavior 16 (4):289-296.

Kelly JB \& Johnson MP (2008) Differentiation among types of intimate partner violence: Research update and implications for interventions. Family Court Review 46 (3):476-499.

Kernsmith P (2010) Treating perpetrators of domestic violence: Gender differences in the applicability of the theory of planned behavior. Sex Roles 52: 757-770.

Kocot T \& Goodman L (2003) The roles of coping and social support in battered women's mental health. Violence Against Women 9 (3):323-346. 
Labronici LM (2012) Resilience in women victims of domestic violence: A phenomenologicalview. Text Context Nursing, Florianópolis 21 (3):625-632.

Leclerc B, Chiu YN, Cale J, \& Cook A (2016) Sexual violence against women through the lens of environmental criminology: Toward the accumulation of evidence-based knowledge and crime prevention. European Journal on Criminal Policy and Research 22 (4):593-617.

LeCouteur A \& Oxlad M (2010) Managing accountability for domestic violence: Identities, membership categories and morality in perpetrators' talk. Feminism \& Psychology 21 (1):5-28.

Levesque DA, Velicer WF, Castle PH, \& Greene RN (2008) Resistance among domestic violence offenders. Violence Against Women 14 (2):158-184.

Liang B, Goodman L, Tummala-Narra P, \& Weintraub S (2005) A theoretical framework for understanding help-seeking processes among survivors of intimate partner violence. American Journal of Community Psychology 36 (1-2):71-84.

Lichtenstein B \& Johnson IM (2009) Older African American women and barriers to reporting domestic violence to law enforcement in the rural deep south. Women \& Criminal Justice 19 (4):286-305.

Marshall GA \& Furr LA (2010) Factors that affect women's attitudes toward domestic violence in Turkey. Violence and Victims 25 (2):265-277.

Mary M (2020) Coping strategies of women intimate partner violence survivors: Perspectives of service providers. Thesis, University of Saskatchewan, Canada.

Mason C (2005) Women, violence and nonviolent resistance in East Timor. Journal of Peace Research $42(6): 737-749$.

Mason G \& Pulvirenti M (2013) Former refugees and community resilience: "Papering over" domestic violence. British Journal of Criminology 53 (3):401-418.

McCarthy M, Hunt S, \& Milne-Skillman K (2016) "I know it was every week, but i can"t be sure if it was every day: Domestic violence and women with learning disabilities. Journal of Applied Research in Intellectual Disabilities 30 (2):269-282.

Meyer A, Wagner B, \& Dutton MA(2009) The relationship between battered women's causal attributions for violence and coping efforts. Journal of Interpersonal Violence 25 (5):900-918.

Miller SL \& Meloy ML (2006) Women's use of force: Voices of women arrested for domestic violence. Violence Against Women 12 (1):89-115.

Mkandawire-Valhmu L, Bauer WS, Stevens PE, Galvao LW, Grande KM, Yerges A, \& Weinhardt L (2016) Rural Malawian women's resistance to systematic oppression, violence, and abuse by their husbands. Journal of Interpersonal Violence. https://doi.org/10.1177/0886260516682518.

Muftić LR, Bouffard JA, \& Bouffard LA (2007) An exploratory study of women arrested for intimate partner violence. Journal of Interpersonal Violence 22 (6):753-774.

Muftić LR, Finn MA, \& Marsh EA (2012) The victim-offender overlap, intimate partner violence, and sex. Crime \& Delinquency 61 (7):899-926.

Myhill A (2017) Measuring domestic violence: Context is everything. Journal of Gender-Based Violence $1(1): 33-44$

Nurhayati SR (2005) Atribusi kekerasan dalam rumah tangga, kesadaran terhadap kesetaraan gender, dan strategi menghadapi masalah pada perempuan korban kekerasan dalam rumah tangga. Thesis, Universitas Gadjah Mada, Yogyakarta.

Payne D \& Wermeling L (2009) Domestic violence and the female victim: The real reason women stay. Journal of Multicultural, Gender and Minority Studies 3 (1).

Purvin DM (2003) Weaving a tangled safety net: The intergenerational legacy of domestic violence and poverty. Violence Against Women 9 (10):1263-1277.

Radford L \& Tsutsumi K (2004) Globalization and violence against women-inequalities in risks, responsibilities and blame in the UK and Japan. Women's Studies International Forum 27 (1):112.

Rajah V (2007) Resistance as edgework in violent intimate relationships of drug-involved women. The British Journal of Criminology 47 (2):196-213.

Randall M (2010) Sexual assault law, credibility, and "ideal victims": Consent, resistance, and victim blaming. Canadian Journal of Women and the Law 22 (2):397-433. 
Rizo CF (2013) The coping efforts of intimate partner violence survivors: Review of the literature, exploratory inquiry, and scale development. Thesis, The University of North Carolina, USA.

Rizo CF (2015) Intimate partner violence related stress and the coping experiences of survivors: "There's only so much a person can handle." Journal of Family Violence 31 (5):581-593.

Rizo CF, Givens A, \& Lombardi B (2017) A systematic review of coping among heterosexual female IPV survivors in the United States with a focus on the conceptualization and measurement of coping. Aggression and Violent Behavior 34: 35-50.

Sayem AM, Begum HA, \& Moneesha SS (2013) Women's attitudes towards formal and informal support-seeking coping strategies against intimate partner violence. International Social Work 58 (2):270-286.

Scarduzio J A, Carlyle K E, Harris KL, \& Savage MW (2016) "Maybe she was provoked." Violence Against Women 23 (1):89-113.

Schaefer LM, Howell KH, Sheddan HC, Napier TR, Shoemaker HL, \& Miller-Graff LE (2019) The road to resilience: Strength and coping among pregnant women exposed to intimate partner violence. Journal of Interpersonal Violence. https://doi.org/10.1177/0886260519850538.

Scott KL \& King CB (2007) Resistance, reluctance, and readiness in perpetrators of abuse against women and children. Trauma, Violence, \& Abuse 8 (4):401-417.

Serran G \& Firestone P (2004) Intimate partner homicide: a review of the male proprietariness and the self-defense theories. Aggression and Violent Behavior 9 (1):1-15.

Sokoloff NJ \& Dupont I (2005) Domestic violence at the intersections of race, class, and gender. Violence Against Women 11 (1):38-64.

Stuart GL (2010) The association between impulsivity, trait anger, and the perpetration of intimate partner and general violence among women arrested for domestic violence. Journal of Interpersonal Violence 26 (13):2681-2697.

Sugg N (2015) Intimate partner violence. Medical Clinics of North America 99 (3):629-649.

Sukmawati B (2014) Hubungan tingkat kepuasan pernikahan istri dan coping strategy dengan kekerasan dalam rumah tangga. Jurnal Sains dan Praktik Psikologi 2 (5):205-218.

Todd N, Wade A, \& Renoux M (2004) Coming to terms with violence and resistance. In: Strong T \& Paré D (Eds) Furthering Talk. Boston: Springer.

Vecina ML, Marzana D, \& Paruzel-Czachura M (2015) Connections between moral psychology and intimate partner violence: Can IPV be read through moral psychology? Aggression and Violent Behavior 22:120-127.

Walby S (1990) Theorizing Patriarchy. Oxford: Basil Blackwell Ltd.

Walton-Moss BJ, Manganello J, Frye V, \& Campbell JC (2005) Risk factors for intimate partner violence and associated injury among urban women. Journal of Community Health 30 (5):377-389.

Warner K, Baro A, \& Eigenberg H (2005) Stories of resistance. Journal of Feminist Family Therapy 16 (4):21-42.

Whitaker MP (2013) Motivational attributions about intimate partner violence among male and female perpetrators. Journal of Interpersonal Violence 29 (3):517-535.

Wilson D, Smith R, Tolmie J, \& de Haan I (2015) Becoming better helpers: Rethinking language to move beyond simplistic responses to women experiencing intimate partner violence. Policy Quarterly 11 (1):25-31.

Yount KM (2005) Resources, family organization, and domestic violence against married women in Minya, Egypt. Journal of Marriage and Family 67 (3):579-596. https://doi.org/10.1111/j.17413737.2005.00155.x.

Yount KM (2010) Women's conformity as resistance to intimate partner violence in Assiut, Egypt. Sex Roles 64 (1-2):43-58.

Zink T, Jacobson CJ, Pabst S, Regan S, \& Fisher BS (2006) A lifetime of intimate partner violence. Journal of Interpersonal Violence 21 (5):634-651. 